\title{
An Assessment of the Microbial Diversity Present on the Surface of Naturally Incubated House Wren Eggs
}

\author{
Beth A. Potter*, Brian M. Carlson, Andrea E. Adams and Margaret A. Voss
}

Department of Biology, The Behrend College, Pennsylvania State University, Erie, PA, 16563, USA

\begin{abstract}
During ovipositioning, avian eggshells become susceptible to bacterial and fungal growth and studies have shown that a community of these microorganisms, or microflora, is maintained on eggshells throughout the incubation process. To determine the possible role of these microorganisms on embryonic development, it is first important to understand the composition of the microbial community present on the surface of the egg. A limited amount of studies have been published in this area; thus, the objective of this study was to broaden this area of study and determine what bacterial communities are found on the surface of naturally-incubated House Wren eggs across three stages of incubation (pre, early, and late) as defined by egg temperature. Our data uniquely suggest that the eggshell microflora is dynamic and that this may be regulated by temperature fluctuations due to intermittent incubation behavior. Using culture-based techniques, 46 different bacterial species were identified belonging to 13 bacterial families and 20 genera. The majority of bacteria belonged to the Pseudomonas, Staphylococcus, Stenotrophomonas, or Burkholderia genera and have been previously associated with avian eggs and nests. Bacteria within the Pseudomonas genus were the most predominant and we hypothesize that their maintenance may be linked to their ability to produce antibiotic substances called bacteriocins. The bacterial composition of the microflora isolated in this study also suggests that avian egg microfloras are derived from environmental origins.
\end{abstract}

Keywords: Avian incubation, bacteria, eggshell, House Wren, Pseudomonas, temperature.

\section{INTRODUCTION}

The primary role of avian incubation, whether intermittent or continuous, is to supply optimal conditions to the egg to maintain embryonic development in regard to temperature, humidity, and gas exchange [1]. This is exemplified by numerous studies that have shown a dramatic decrease in viability in the absence of incubation [2-5]. Emerging research suggests that a secondary role of incubation is the delicate maintenance of a microflora on the shell that limits potentially pathogenic bacteria $[5,6-10])$. The bacteria that comprise this microflora have multiple possible origins. The bacteria may be transferred directly from the mother either from the posterior reproductive tract, feces, or from direct contact with the egg during the incubation period $[6,11,12]$. Alternatively, the bacteria may have an environmental origin and be introduced to eggs via nest materials, which has been shown to be important for fungal associations $[13,14]$.

Interest in the bacterial microflora of egg surfaces first arose in commercial hatcheries. Subsequent studies described mechanisms for trans-shell migration and a reduction in egg viability $[6,11]$. Only relatively recently have studies begun to look into the composition or the implications of this microflora during natural incubation. In 2005, a study involving Pearly-eyed Thrashers in a tropical environment was the first to show that incubation limits microbial infection [7]. In that study all parentally incubated eggs had limited

*Address correspondence to this author at the Penn State Erie, The Behrend College, 4205 College Drive, Erie, PA 16563, USA; Tel: 814-898-6510; Fax: 814-898-6213; Email: bap16@psu.edu growth on the surface of the egg and were free of infections, whereas a significant percentage of unincubated eggs demonstrated higher microbial loads on the surface of the egg and bacterial infection (90\% at a cool, humid highland location and $28 \%$ at a hotter, less humid lowland location) [7]. In a subsequent study, Cook et al. (2005) showed that nonincubated eggs had higher microbial loads of gram-negative enterics, gram-negative fermenters, and gram-positive cocci (considered pathogenic) while parentally incubated eggs showed a decrease in these three categories and a slight increase in gram positive rods (not considered as pathogenic) over the first several days of incubation [8]. A similar trend was also seen when culture-independent methods were used, providing further support to the theory that parental incubation has a role in limiting and/or enhancing the bacterial microflora [9].

Whereas the studies described above shifted emphasis from commercial hatcheries to natural incubation, they were all focused on one bird species, the Pearly-eyed Thrasher, in a tropical environment. It remains unclear whether this is a widely-observed trend applicable to a variety of birds and climates. Two recent papers have broadened the research scope. Ruiz-de-Castaneda et al worked with Pied Flycatchers in the temperate environment of central Spain to show that the bacterial microflora of eggshells were essentially static throughout the entire incubation period [15]. These data conform to the trend observed for the Pearly-eyed Thrasher in tropical environments. Data from a North American temperate environment for Western Bluebird, Tree and Violet-green Swallows, however, showed no significant increase in microbial loads on eggshells or bacterial infection when paren- 
tally incubated eggs were compared to those that were nonincubated [5]. This suggests that the relationship between natural incubation behavior and the microflora of avian eggs does not conform to a single representative trend; it is potentially more complicated and may be unique to individual prenatal nesting environments. It would be quite surprising to find that cavity nesting birds in forested areas support egg microbial communities comparable to those of open cup nesting species in grassland areas. Since few descriptive studies of the microbial diversity of eggs in natural nests exist, it becomes important to characterize the microbial populations associated with a variety of bird species and habitats. The data presented in this paper represent a step toward elucidating the precise relationship between incubation behavior and ecosystem-based factors.

Our study focused on the egg surface mircoflora of the House Wren (Troglodytes aedon) breeding in a temperate region. We identified bacteria found on the surface of parentally incubated eggs across entire incubation periods using culture-dependent methods. Our study objectives were to add to the existing data regarding the composition of the bacterial normal flora of avian eggshells and to determine whether the diversity fluctuates with the changes in temperature that occur over the course of embryo development as a function of the natural incubation behavior of the House Wren.

\section{MATERIALS AND METHODOLOGY}

\section{Study Species and Field Site}

House Wren breeding distribution includes both tropical and temperate regions, crossing almost the entire Western Hemisphere from the central Canadian plains to the southernmost tip of South America [16]. A typical House Wren clutch consists of 5-12 eggs [17], with the largest clutches occurring in the highest latitudes [18]. Data for this study were collected from wrens nesting in a network of 50 standard size Bluebird boxes during the 2005 to 2012 breeding seasons. The nest box network has been maintained and monitored since 2002 in Southwestern New York and Northwestern Pennsylvania near Erie, PA (42 ${ }^{\circ} 7^{\prime} 45^{\prime \prime} \mathrm{N} / 80^{\circ}$ 5' 7" W) and have been exclusively used by House Wrens.

\section{Determination of Average Daily Egg Temperatures within Nests}

We used temperature data from 23 House Wren nests monitored daily and continuously from 15 May to 31 July during the 2005 to 2012 breeding seasons to determine parental attentiveness and average egg temperature patterns. A repeated mixed model analysis showed that average nest temperatures did not vary across year $(p=0.7383)$. The number of eggs present in each nest were recorded daily. When 2 eggs were found in a given nest, a programmable Thermocron temperature probe (iButton, Maxim) was attached to nest material inside the nest cup. Nest temperature data were collected every $30 \mathrm{~s}$ continuously for the entire incubation period for each nest monitored. Temperature fluctuations in the nest cup were used to derive female behavior patterns [19]. We used the software combination of Rhythm and Raven [20] to view the data and compute the duration of all female recesses from the nest across each day of data. Nest attendance was found by $\Sigma$ (recess durations/active day)*100, with active day equal to the duration between the start of the first recess of a day and the end of the last recess. Egg temperature records were also collected using miniature battery powered dual-channel ambient temperature and remote thermocouple data loggers (OM-CP-TC4000, Omega Engineering Inc.) placed on the bottom of nest boxes and beneath nests. To measure egg temperatures, we attached to the remote port of each data logger a factory welded 36gauge constantan-chromega thermocouple (Omega Engineering Inc, Stamford Connecticut) implanted in plastic craft eggs $(1.5 \mathrm{~cm} \times 1.2 \mathrm{~cm})$ that resembled House Wren eggs in both size and coloration and filled with silicon gel (Ideal Industries, Sycamore Illinois). Like nests, egg temperatures were recorded every 30 s during the incubation period. Temperature data was not recorded for nests that were used for microbial data.

\section{BACTERIAL SAMPLING}

Clutch initiation dates ranged from May 19 to July 2 for the 2010 season. Egg surface microflora samples were taken daily after the first egg in each clutch was detected. Aseptic techniques were utilized to the furthest extent possible in a field setting. Eggs were removed with a gloved hand and a sterile plastic stencil $(7 \mathrm{~mm} \times 10 \mathrm{~mm}$ rectangle) was placed over the egg to limit microflora samples to a standardized area. Samples were taken with a sterile swab slightly saturated in sterile nutrient broth. Each swab was placed in nutrient broth in an individually labeled microfuge container and stored at $4^{\circ} \mathrm{C}$ until processing using culture-based techniques. More than 300 microbial samples were obtained from eggs in 19 House Wren nests. The average clutch size for this population in 2010 was $6 \pm 1.9$ eggs. Samples were processed over a time period of 6 months. Samples were assigned to the categories of "pre-incubation", "early incubation", or "late incubation" based on the increases in female attentiveness on the nest throughout the incubation period. The data analysis for the egg temperature records followed this classification scheme as well.

\section{Bacterial Identification Methods}

To remove bacteria from swabs, the tubes containing the swabs and nutrient broth were vortexed for 30 seconds. After vortexing, the broth was immediately sampled and used for serial dilutions and plating. Samples were serially diluted up to $10^{\wedge}-8$ and plated on nutrient agar and incubated at $30^{\circ} \mathrm{C}$ and $37^{\circ} \mathrm{C}$ (the majority of the growth was isolated on plates grown at $30^{\circ} \mathrm{C}$ ). Plates were incubated for $48 \mathrm{hrs}$. After incubation, a countable plate, containing 30-300 total colony forming units (CFUs), was obtained. CFUs were characterized based on morphology and unique colonies were streaked for isolation. The DNA from a representative unique colony was isolated and was subsequently used in PCR reactions to amplify the $16 \mathrm{~S}$ rRNA gene and obtain sequencing information to determine the genus and species of the bacteria.

To isolate DNA, a pure colony of bacteria was placed in $50 \mu \mathrm{ls}$ of water and cells were lysed using a freeze-thaw method. Samples were placed in a methanol/dry ice bath for two minutes then placed in the heating block $\left(99^{\circ} \mathrm{C}-105^{\circ} \mathrm{C}\right)$ for 2 minutes. This cycle was repeated two more times to 
insure lysis of cellular membranes and exposure of the DNA. Lysed cells were centrifuged for five minutes at 13,000 RPM. The supernatant, containing DNA, was removed and known as the DNA stock. To identify bacterial species, the $16 \mathrm{~S}$ ribosomal gene was amplified from the extracted DNA using the universal bacterial primers $27 \mathrm{~F}$ (5'AGAGTTTGATCATGGCTCAG-3') and 1487R (5'TACCTTGTTACGACTTCACC-3') [21]. During the course of this research, the primer combination was switched to primers 8F (5'-AGAGTTTGATCCTGGCTCAG-3') and 1495R (5'-CTACGGCTACCTTGTTACGA-3') due to better yields [22]. All PCR reactions were performed in an Applied Biosystems GeneAmp 9700 Thermocycler with a $25 \mu \mathrm{l}$ volume containing: $1-2 \mu \mathrm{ls}$ of DNA, $1 \mu \mathrm{l}$ of each primer (10 $\mu \mathrm{M}), 9.5-10.5 \mu \mathrm{ls}$ of $\mathrm{H}_{2} \mathrm{O}$, and $12.5 \mu \mathrm{ls}$ of KOD hot start master mix (EMD Millipore). Reactions were initiated with a denaturation step at $95^{\circ} \mathrm{C}$ for $2 \mathrm{~min}$, followed by 40 cycles of denaturation $\left(95^{\circ} \mathrm{C}\right.$ for $\left.20 \mathrm{sec}\right)$, annealing $\left(54^{\circ} \mathrm{C}\right.$ for $\left.10 \mathrm{sec}\right)$, and extension $\left(70^{\circ} \mathrm{C}\right.$ for $\left.20 \mathrm{sec}\right)$. After PCR, DNA amplification was verified using gel electrophoresis. If bands were seen at $1400 \mathrm{bp}$, reactions were incubated with ExoSAP (Affymetrix) for $15 \mathrm{~min}$ at $37^{\circ} \mathrm{C}$ then $15 \mathrm{~min}$ at $80^{\circ} \mathrm{C}$. The ExoSAP product was sent with $1 \mu \mathrm{M}$ primers $(27 \mathrm{~F} / 1487 \mathrm{R}$ or $8 \mathrm{~F} / 1495 \mathrm{R}$ ) for sequencing at the Genomics Core Facility at Penn State University Park. Forward and reverse sequences were used to construct a consensus sequence with Geneious software (Biomatters Ltd). Consensus sequences were run through NCBI-BLAST/EzTaxon to determine the genus and species of bacterial isolates.

\section{STATISTICAL ANALYSIS}

We used maximum likelihood estimation, in the form of a $G$-test, to detect changes in the proliferation of colony forming units for each phylotype across all three stages of incubation. The general formula for a $G$ test is:

$$
G=2, i--, O-i . . *, \ln -,,, O-i .-, E-i \ldots .
$$

Where $O$ is the number of colony forming units per phylotype per incubation stage and $E$ is the expected number of colony forming units per phylotype per incubation stage.

Phylotype richness was calculated as the number of phylotypes isolates counted per sample. Phylotype diversity was calculated using the equation

$D=\Sigma$,\# observations of a given isolate-total \# of observations of all isolates.

Prominence values (PV) were used to track changes in the prevalent phylotypes across all three stages of incubation according to the formula:

$$
\begin{aligned}
& P V=\text {,isolate cfu/ml-\#samples.*,-frequency. isolate } \\
& \text { occured in samples }
\end{aligned}
$$

\section{RESULTS}

Intermittent incubation behavior is relatively common among most passerine bird species, but there are most likely subtle differences in this behavior among avian species [23]. For instance the degree to which eggs warm and cool would likely vary and we believe this would affect the microbial flora found on egg shells. Thus, we first chose to track the time female House Wrens (males do not incubate eggs) spend on the nest and the temperature of House Wren eggs throughout the incubation period. Nest temperature fluctuations due to the female leaving and returning were used to determine the female's time on the nest (Fig. 1). The female spent the least amount of time on the nest during the first few days of the incubation period. Nest attentiveness did increase on the fourth day of incubation which typically coincided with the laying of the fourth egg. Clutch completion usually occurred on the eighth day of incubation and a second increase in female attentiveness was observed on this day and maintained through the incubation period. Based on these data we divided the incubation period for House Wrens into three stages: pre-, early, and late incubation. We defined the "pre-incubation stage" as the time between the laying of the first and fourth eggs during which the female spends little time on the nest. "Early incubation" was defined as the time between the laying of the fourth egg and clutch completion. "Late incubation" was defined as the time between clutch completion and hatching and included the highest daily nest attentiveness by the female. Using decoy eggs containing a thermocoupled data logger, egg temperatures were recorded throughout these stages and the average egg temperature increased from $16.3^{\circ} \mathrm{C}$ during pre-incubation to $24.1{ }^{\circ} \mathrm{C}$ in early incubation and to $31.05^{\circ} \mathrm{C}$ in late incubation (Fig. 2).

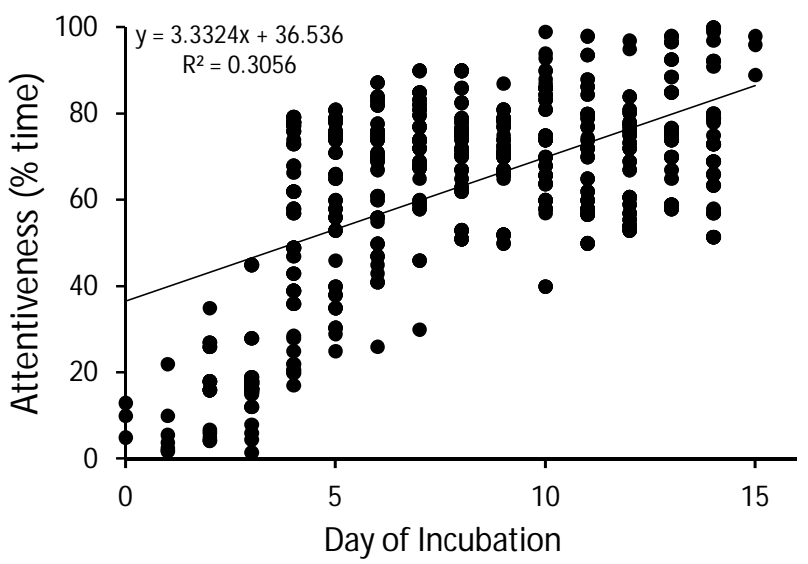

Fig. (1). Nest attentiveness of female House Wrens throughout incubation.

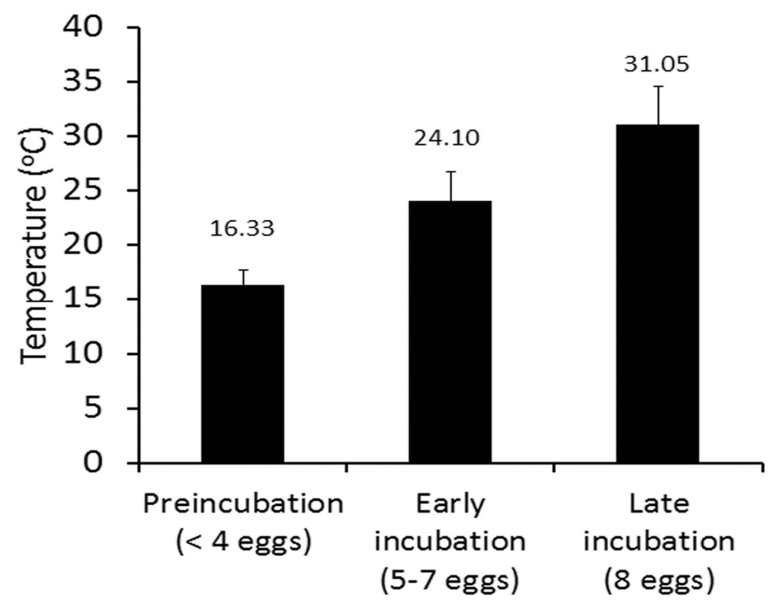

Fig. (2). Average egg temperatures in naturally incubated House Wrens nests during pre, early, and late incubation. 
Bacterial phylotypes were isolated from swabs of eggshell surfaces obtained during each incubation period and identified using $16 \mathrm{~S}$ rRNA sequencing techniques. In total, we identified 46 different phylotypes within 20 different genera from 313 egg microflora samples (Table 1). Throughout the incubation period the majority $(>90 \%)$ of bacteria isolated belonged to either the Pseudomonas, Staphylococcus, Burkholderia, and Stenotrophomonas genera. However, the microbial populations were not as static as the previous statement suggests. The 15 other bacterial genera were more transient within the eggshell microflora usually appearing in only one of the incubation stages. For instance, bacteria within the Erwinia genus were only found in the pre-incubation stage. Eight bacterial genera (Brevibacillus, Cellulomonas, Enterobacter, Enterococcus, Luteibacter, Pectobacterium, Rhodanobacter, and Sanguibacter) were specific to early incubation and five genera (Bacillus, Massilia, Plantibacter, Rahnella, and Rhodococcus) were specific to the late incubation stage. Two genera were found to span two incubation stages: the Paenibacillus genus was found in both the pre- and early incubation stages and bacteria within the Pantoea genus were isolated in the early and late incubation stages. Thus, over the course of the incubation period, a total of 6 genera were isolated during the pre-incubation stage, 14 genera during the early incubation stage, and 10 genera during the late incubation stage. Fluctuations also occurred at the species level within the predominant genera, which led to an increased species richness value in early incubation ( $\mathrm{N}=54$ phylotypes) compared to the pre-incubation and late incubation stages $(\mathrm{N}=42$ and $\mathrm{N}=43$ phylotypes, respectively).

Of the predominant genera the only bacteria isolated from all incubation stages and individual nests was Pseudomonas (Fig. 3). Of the 15 identified phylotypes within this genus, Pseudomonas flourescens was ubiquitous; it was isolated across all incubation stages (pre, early, and late) and from multiple eggs and nests $(\mathrm{N}=19)$. This was followed by Pseudomonas koreensis, Pseudomonas putida, and Pseudomonas poae, listed in respective order of isolation frequency. The number of combined Pseudomonas colonies (cfu/ml) isolated per incubation stage (pre, early, late) was not statistically different across the three stages of incubation (F2, $45=0.01 . \mathrm{p}=0.9924$ ). However, the distribution of colony forming units of individual phylotypes did change significantly with incubation stage (Table 2).

We used prominence values to track changes in the prevalent phylotypes of Pseudomonas across all three stages of incubation (Table 3). P. fluorescens was the most prominent phylotype of bacteria cultured in pre- and early- incubation, while $P$. putida increased in prominence late in incubation.

\section{DISCUSSION AND CONCLUSION}

House Wrens are among the $62 \%$ of passerine species that exhibit intermittent incubation behavior [24]. The affect this behavior has on the microflora maintained on eggshells likely varies for different avian species; thus we monitored the attentiveness of the female House Wren on the nest and the average egg temperature throughout the incubation period of several House Wrens within different nests and over multiple years. The data show that increases in female attentiveness correlate with increases in the average egg temperature, consistent with patterns observed in other passerine species [23]. Egg temperature changes are especially important when examining bacterial populations because bacteria do not have the ability to thermoregulate. Our culture-based analysis of phylotype abundance at each stage of incubation suggests that House Wrens foster a dynamic microflora on their eggshells. As postulated in previous studies the presence of a microflora could be influential in preventing the growth of pathogenic species and/or allowing shell modifications, such as an increase in water vapor permeability, that are necessary for embryo development $[5,6-10,13]$. The data from our study suggests that the fluctuations within the microflora may be regulated by the observed temperature changes throughout the incubation period. Thus bacteria within the Pseudomonas, Staphylococcus, Burkholderia, and Stenotrophomonas genera predominate because these bacteria are able to thrive throughout the temperature range, whereas the transient bacteria are relegated to specific incubation stages due to the temperature changes. An increase in the genera represented and species richness during the early incubation stage suggests that the optimal temperature for bacterial growth on the eggshell is approximately $24.1^{\circ} \mathrm{C}$. The dynamic nature of the microflora could also be explained by indirect rather than directs effects of temperature on growth. It is possible that the fluctuations in temperature may regulate the production of antibacterial substances by members of the microflora and limit the growth of certain bacteria. It is important to mention that previous studies showed species richness was static throughout the incubation period $[9,15]$; however, those studies did not include a sampling date that was equivalent to our early incubation stage.

The four genera (Pseudomonas, Staphylococcus, Stenotrophomonas (Xanthomonas), and Burkholderia) maintained throughout the incubation period have been previously associated with avian eggshells and nests. Overall, Pseudomonas was the most commonly isolated genus. This study is not the first to report an abundance of Pseudomonas; bacteria within this genus were also most common on eggshells of Pied Flycatchers [15]. Pseudomonas has also been isolated from old House Wren nests and the nests of the Great Tit and Blue Tit; these studies reported a high proportion of Staphylococcus as well [25, 26]. Stenotrophomonas was previously isolated from the eggshells of Pearly-eyed Thrashers and Burkholderia has been isolated from the female cloaca of Pied Flycatchers $[9,15]$. The similarity between the bacteria in this study and previous studies of birds nesting in different habitats (e.g., temperate versus tropical or grassland versus forest) may suggest a common mechanism inherent within birds that leads to the maintenance of a similar microflora. For instance, uropygial glands, which have been shown to have antimicrobial properties, may be involved [27-30]. The antibacterial properties of this gland's secretions have been linked to fatty acids and alcohols within uropygial oil [27]. Interestingly, in a study done by Shawkey et al. examining the effectiveness of uropygial oil, there was no effect against phylotypes of bacteria found within Pseudomonas, the most predominant genus isolated in our study [27]. The antimicrobial properties of the gland have also been linked to a specific bacterium, Enterococcus faecalis, 
Table 1. Characterization of Bacterial Isolates Identified from the Surface of Naturally-Incubated House Wren Eggs and the Number of Detections in Each Stage of Incubation

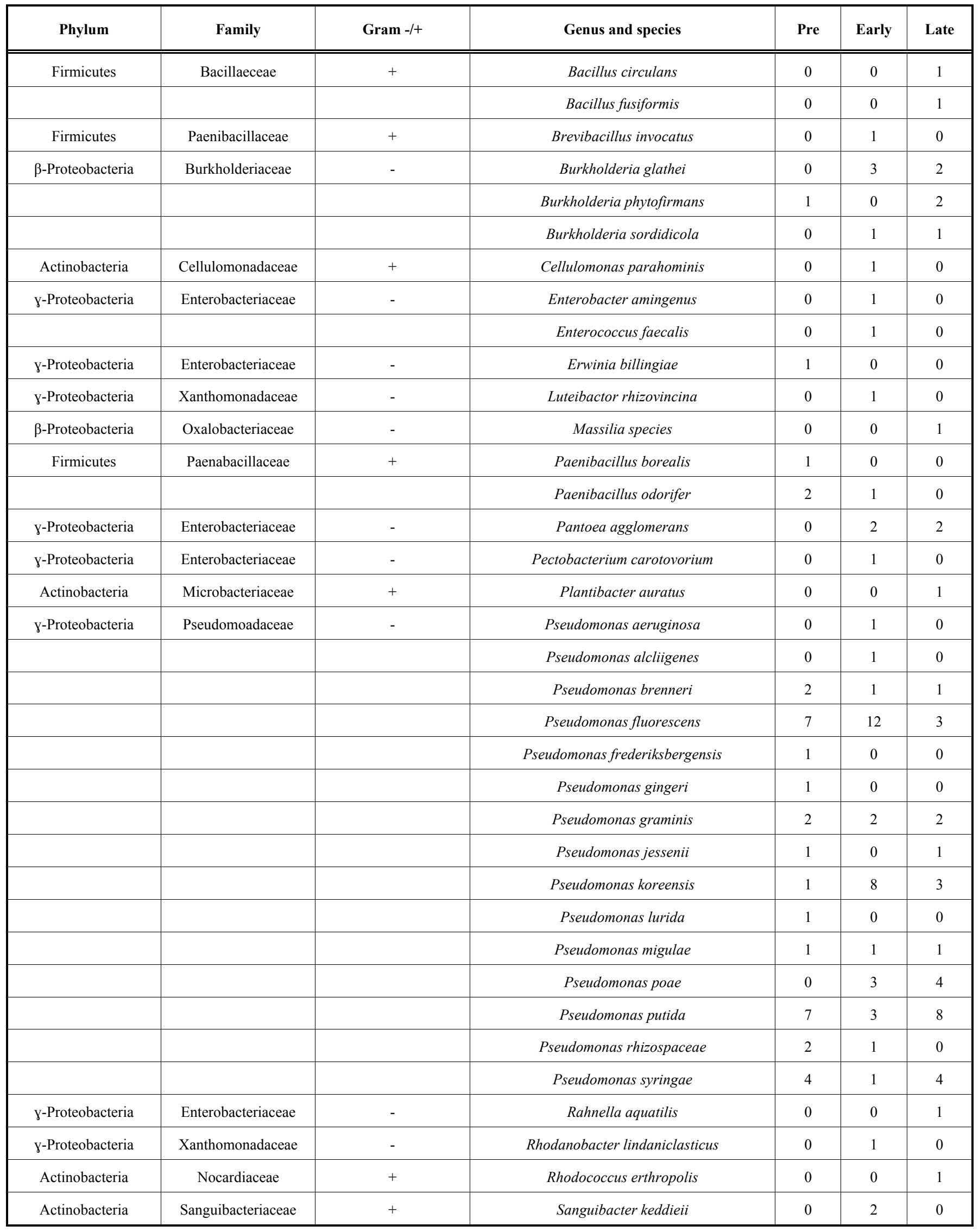


(Table 1) contd....

\begin{tabular}{|c|c|c|c|c|c|c|}
\hline \multirow[t]{2}{*}{ Firmicutes } & Staphylococcaceae & + & Staphylococcus epidermidis & 0 & 1 & 1 \\
\hline & & & Staphylococcus succinus & 1 & 2 & 0 \\
\hline y-Proteobacteria & Xanthomonadaceae & - & Stenotrophomonas maltophilia & 0 & 0 & 1 \\
\hline
\end{tabular}

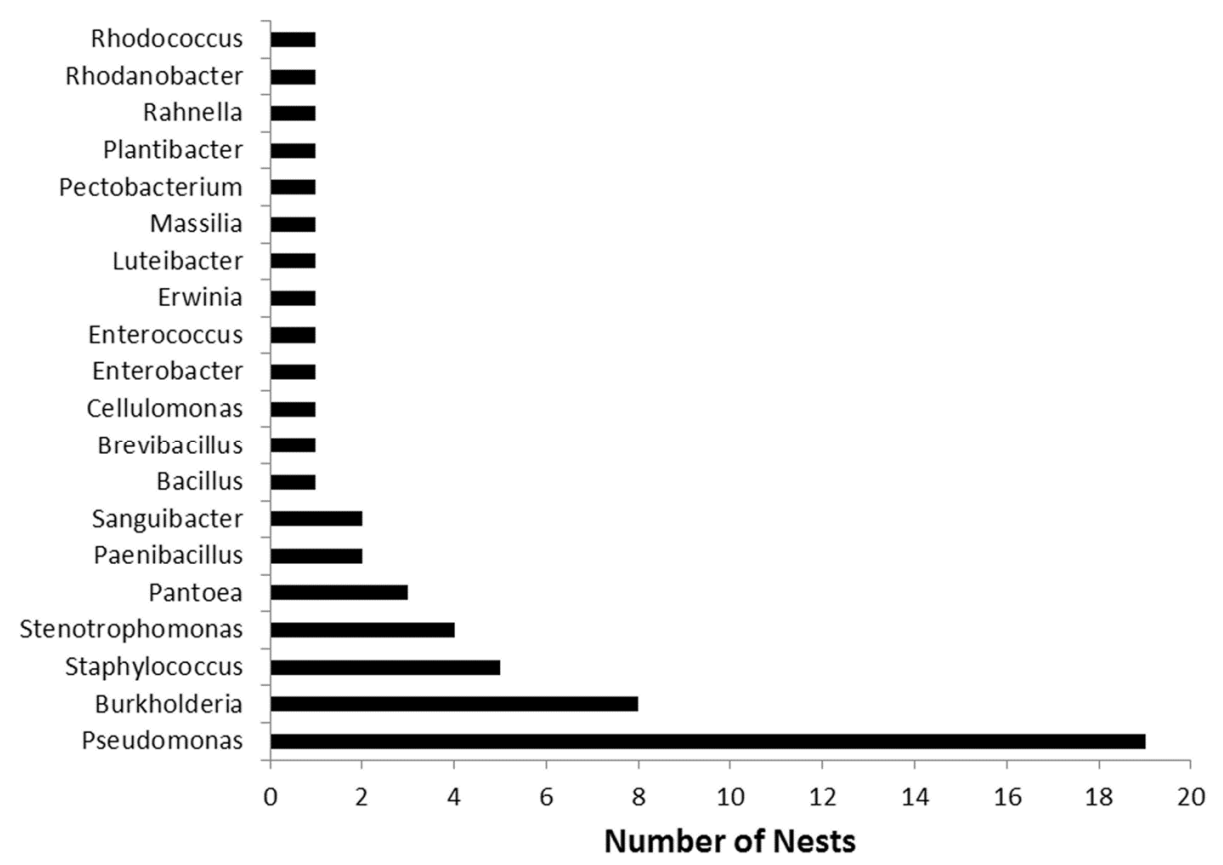

Fig. (3). Distribution of bacterial genera on House Wren eggs. A total of 19 nests were sampled.

which has been isolated from uropygial secretions [29, 30]. $E$. faecalis produces antibacterial substances termed bacteriocins that have shown effectiveness against the featherdegrading bacterium Bacillus licheniformis as well as several others $[29,30]$. This bacteria was found in at least one of the nests used in this study.

An alternative explanation for the predominance of four genera on House Wren eggshells may be the ability of these bacteria to produce their own antibiotic substances called bacteriocins [31-33]. In Pseudomonas, these antibiotic substances are referred to as pyocins [34]. Most research has focused on $P$. aeruginosa [34, 35] but $P$. fluorescens $[34,36$, 37], and $P$. syringae [38] have been shown to produce these antibacterial substances and were all identified in our study. The pyocins from various species have been shown to have broad-spectrum capabilities and were effective against members of the pathogenic Enterobacteriaceae family including Escherichia coli and Salmonella [39]. Interestingly, very few genera from the Enterobacteriaceae family (Pantoea, Rahnella, Luteibacter, and Pectobacterium) were isolated and all had very low numbers (less than $2 \%$ ). Research has also shown that bacteriocin production may be temperature regulated [40]. The optimal temperature for pyocin production in
P. solanacearum was $30^{\circ} \mathrm{C}$ [40] and if similar regulation occurs in the Pseudomonas phylotypes identified within our study it could explain why the total bacterial number and diversity did not increase through the late incubation stage. Importantly, when Pseudomonas was prevalent on the eggshells of Pied Flycatchers there was no correlation between the presence of Pseudomonas and negative effects on hatching success [15].

The bacterial populations identified in this study also suggest that the phylotypes comprising the microflora have environmental origins as opposed to vertical transmission from either parental digestive or reproductive tracts. Ruizde-Castaneda et al. found evidence for the latter, but it was not evident for Pseudomonas [15]. The majority of the bacteria isolated in this study belong to the Firmicutes phylum and the $\beta$ - and $\gamma$-Proteobacteria subdivisions. Our results correlate with a study examining bacteria isolated from feathers of Eastern Bluebirds and were associated with soil bacteria [41]. Additionally the identified temperature range between the early and late incubation stages includes the optimal temperature range $\left(25-30^{\circ} \mathrm{C}\right)$ for soil microorganisms [42]. These data suggest that birds may pick up various bacteria on their feathers when foraging for food and then transfer 
Table 2. The Concentration of Colony Forming Units Significantly Changed Across the Three Stages of Parental Incubation for 16 Phylotypes of Pseudomonas Isolated from HOUSE Wren Eggs

\begin{tabular}{|c|c|c|c|c|c|c|}
\hline Strain & Pre (cfu/ml) & Early (cfu/ml) & Late $(\mathrm{cfu} / \mathrm{ml})$ & df & G & $\mathbf{p}$ \\
\hline P. aeruginosa & 0 & 140000000 & 0 & 2 & 307611440.8 & $0.00 \mathrm{E} 0$ \\
\hline P. alcligenes & 0 & 99000000 & 0 & 2 & 217525233.2 & $0.00 \mathrm{E} 0$ \\
\hline P. brenneri & 186800000 & 300000000 & 10300000 & 2 & 343714155.6 & $0.00 \mathrm{E} 0$ \\
\hline P. fluorescens & 2115300000 & 3413391000 & 910096000 & 2 & 1544400272 & $0.00 \mathrm{E} 0$ \\
\hline P. frederiksbergensis & 140000000 & 0 & 0 & 2 & 307611440.8 & $0.00 \mathrm{E} 0$ \\
\hline$P$. gingeri & 31000 & 0 & 0 & 2 & 68113.962 & $0.00 \mathrm{E} 0$ \\
\hline P. graminis & 187000000 & 1070000000 & 7224480 & 2 & 1631454038 & $0.00 \mathrm{E} 0$ \\
\hline P. jessenii & 640000 & 0 & 530000000 & 2 & 1156053947 & $0.00 \mathrm{E} 0$ \\
\hline P. koreensis & 202000000 & 1774100000 & 507000000 & 2 & 1638343251 & $0.00 \mathrm{E} 0$ \\
\hline P. lurida & 680000000 & 0 & 0 & 2 & 1494112713 & $0.00 \mathrm{E} 0$ \\
\hline P. migulae & 2470000000 & 70000000 & 130000000 & 2 & 4186374422 & $0.00 \mathrm{E} 0$ \\
\hline P. poae & 43000000 & 1150400000 & 1391000000 & 2 & 1740650269 & $0.00 \mathrm{E} 0$ \\
\hline P. putida & 1044800000 & 238000000 & 3790000000 & 2 & 4178334165 & $0.00 \mathrm{E} 0$ \\
\hline P. rhizosphaceae & 320900000 & 117000000 & 0 & 2 & 453816942.6 & $0.00 \mathrm{E} 0$ \\
\hline P. syringae & 358000000 & 41000000 & 552000000 & 2 & 531700396.9 & $0.00 \mathrm{E} 0$ \\
\hline$P$. veronii & 560000000 & 0 & 0 & 2 & 1230445763 & $0.00 \mathrm{E} 0$ \\
\hline
\end{tabular}

We Assumed an Expected Ratio of 1:1:1 cfu/ml Across All Stages of Parental Incubation and a Significance Level of 0.05 for the G-Test

Table 3. Prominence Values for the Most Common Phylotypes of Pseudomonas Isolated from House Wren Eggs Across 3 Stages of Incubation

\begin{tabular}{|c|c|c|c|c|c|c|}
\hline Order & Pre-incubation & PV & Early incubation & PV & Late incubation & PV \\
\hline \hline 1 & P. fluorescens & 23891619.8 & P. fluorescens & 50477898.6 & P. putida & 45762401.7 \\
\hline 2 & P. putida & 11800673.4 & P. koreensis & 21421392.3 & P. poae & 11876315.6 \\
\hline 3 & P. migulae & 10544392.4 & P. poae & 8506170.9 & P. fluorescens & 6729339.5 \\
\hline 4 & P. syringae & 3056593.1 & P. graminis & 6459864.1 & P. koreensis & 3748807.9 \\
\hline
\end{tabular}

bacteria to the egg when they return to the nest. However, Bisson et al. found a significant difference in the bacteria isolated on feathers and in soil suggesting that other factors may also be important in defining the bacterial populations maintained on eggshells [43].

In conclusion, the bacterial flora that exist on the surface of eggshells appear to be influenced, and possibly regulated, by the incubation behavior of the House Wren. Our work represents a first step toward a better understanding of the role bacterial flora may play in embryonic development; including identifying the precise origin of the bacterial flora, exact compositions, and how the delicate balance between beneficial and potentially pathogenic bacteria is maintained over the course of incubation.

\section{CONFLICT OF INTEREST}

The author(s) confirm that this article content has no conflicts of interest.

\section{ACKNOWLEDGEMENT}

We would like to thank Michael Campbell and the students of the Spring 2011 BMB406 Molecular class for working out the freeze-thaw DNA isolation procedure and analyzing several samples. Several students assisted in both field and lab components of this study, including Craig Richards, Megan Fleming, Nicolas Kniseley and Christian Mosebach. Funding for this project was provided by the Penn State Behrend Undergraduate Student Research Grant Program to B. Potter and M. Voss. 


\section{REFERENCES}

[1] Deeming DC. Avian incubation behaviour, environment and evolution. In: Deeming DC, Ed. Importance and evolution of incubation in avian reproduction. New York: Oxford University Press 2002; pp. 179-91.

[2] Webb DR. Thermal tolerance of avian embryos: A review. Condor 1987; 89(4): 874-98.

[3] Veiga JP, Viñuela J. Hatching asynchrony and hatching success in the house sparrow: evidence for the egg viability hypothesis. Ornis Scand 1993; 24: 237-42.

[4] Viñuela J. Opposing selective pressures on hatching asynchrony: egg viability, brood reduction, and nestling growth. Behav Ecol Sociobiol 2000; 48: 333-43.

[5] Wang JM, Firestone MK, Beissinger SR. Microbial and environmental effects on avian egg viability: do tropical mechanisms act in a temperate environment? Ecology 2011; 92: 1137-45.

[6] Cook MI, Beissinger SR, Toranzos GA, Rodriguez, RA, Arendt WJ. Trans-shell infection by pathogenic micro-organisms reduces the shelf life of non-incubated bird's eggs: a constraint on the onset of incubation? Proc R Soc Lond B 2003; 270: 2233-40.

[7] Cook MI, Beissinger SR, Toranzos GA, Rodriguez RA, Arendt WJ. Microbial infection affects egg viability and incubation behavior in a tropical passerine. Behav Ecol 2005; 16: 30-6.

[8] Cook MI, Beissinger SR, Toranzos GA, Arendt WJ. Incubation reduces microbial growth on eggshells and the opportunity for trans-shell infection. Ecol Lett 2005; 8: 532-7.

[9] Shawkey MD, Firestone MK, Brodie EL, Beissinger SR. Avian incubation inhibits growth and diversification of bacterial assemblages on eggs. PLoS ONE 2009; 4:e4522.

[10] Wang JM, Beissinger SR. Partial incubation in birds: Its occurrence, function, and quantification. Auk 2011; 128 (3): 454-66.

[11] Bruce J, Drysdale EM. Microbiology of avian eggs In: Board RG, Fuller R, Eds. Trans-shell transmission. London: Chapman \& Hall 1994; pp. 63-91.

[12] Barrow PA. 1994. Microbiology of avian eggs. In: Board RG, Fuller R, Eds. The microflora of the alimentary tract and avian pathogens: translocation and vertical transmission. London: Chapman \& Hall 1994; pp. 117-36.

[13] Baggott GK, Graeme-Cook K. Avian incubation behaviour, environment and evolution. In: Deeming DC, Ed. Microbiology of natural incubation. New York: Oxford University Press 2002; pp. 179-91.

[14] Peralta-Sanchez JM, Moller AP, Martin-Platero AM, Soler JJ. Number and colour composition of nest lining feathers predict eggshell bacterial community in Barn Swallow nests: an experimental study. Funct Ecol 2010; 24: 426-33.

[15] Ruiz-de-Castaneda R, Vela AI, Lobato E, Briones V, Moreno J. Prevalence of potentially pathogenic culturable bacteria on eggshells and in cloacae of female Pied flycatchers in a temperate habitat in central Spain. J Field Ornithol 2011; 82(2): 215-24.

[16] Peterson RT, Peterson VM. Birds of eastern and central North America. $5^{\text {th }}$ ed. New York: Houghton Mifflin Company 2002.

[17] Baicich PJ, Harrison CO. A guide to the nests, eggs, and nestlings of North American birds. $2^{\text {nd }}$ ed. San Diego: Academic Press 1997.

[18] Murray BG. Evolution of clutch size in tropical species of birds. Ornithol Monogr 1985; 36: 505-19.

[19] Joyce EM, Sillett TS, Holmes RT. An inexpensive method for quantifying incubation patterns of open-cup nesting birds, with data for Black-throated Blue Warblers. J Field Ornithol 2001; 72: 36979.

[20] Cooper CB, Mills H. Software to quantify incubation behavior from time series recordings. J Field Ornithol 2005; 76: 352-6.

[21] Heddi A, Grenier AM, Khatchadourian C, Charles H, Nardon P. Four intracellular genomes direct weevil biology: nuclear, mitochondrial, principal endosymbiont, and Wolbachia. Proc Natl Acad Sci USA 1999; 96: 6814-9.

[22] Grifoni A, Bazzicalupo M, DiSerio C, Fancelli S, Fani R. Identification of Azospirillum strains by restriction fragment length polymorphism of the 16S rDNA and of the histidine operon. FEMS Microbiol Lett 1995; 127: 85-91.
[23] Cooper CB, Voss MA. Avian Incubation Patterns Reflect Temporal Changes in Developing Clutches. PLoS ONE 2013; 8(6): e65521. doi:10.1371/journal.pone.0065521

[24] Deeming DC. Avian incubation behaviour, environment and evolution. In: Deeming DC, Ed. Behavior patterns during incubation. New York: Oxford University Press 2002; pp. 63-87.

[25] Singleton DR, Harper RG. Bacteria in old House wren nests. J Field Ornithol 1998; 69(1): 71-4.

[26] Goodenough AE, Stallwood B. Intraspecific variation and interspecific differences in the bacterial and fungal assemblages of Blue tit (Cyanistes caeruleus) and Great tit (Parus major) nests. Microb Ecol 2010; 59: 221-32.

[27] Shawkey MD, Shreekumar RP, Hill GE. Chemical warfare? Effects of uropygial oil on feather-degrading bacteria. J Avian Biol 2003; 34: 345-9.

[28] Martin-Platero AM, Valdivia E, Ruiz-Rodriguez M, et al. Characterization of antimicrobial substances produced by Enterococcus faecalis MRR 10-3, isolated from the Uropygial gland of the Hoope (Upupa epops). Appl Environ Microbiol 2006; 72(6): 42459.

[29] Soler JJ, Martin-Vivaldi M, Ruiz-Rodriguez M, et al. Symbiotic association between hoopoes and antibiotic-producing bacteria that live in their uropygial gland. Funct Ecol 2008; 22: 864-71.

[30] Ruiz-Rodriguez M, Valdivia E, Soler JJ, Martin-Vivaldi M, Martin-Platero AM, Martinez-Bueno M. Symbiotic bacteria living in the hoopoe's uropygial gland prevent feather degradation. J Exp Biol 2009; 212: 3621-6.

[31] Compant S, Nowak J, Coenye T, Clement C, Barka EA. Diversity and occurrence of Burkholderia spp. in the natural environment. FEMS Microbiol Rev 2008; 32: 607-26.

[32] Bastos MCF, Ceotto H, Coelto MLV, Nascimento JS. Staphylococcal antimicrobial peptides: relevant properties and potential biotechnological applications. Curr Pharm Biotechnol 2009; 10: 3861.

[33] Hayward AC, Fegan N, Fegan M, Stirling GR. Stenotrophomonas and Lysobacter: ubiquitous plant-associated gamma-proteobacteria of developing significance in applied microbiology. J Appl Microbiol 2009; 108: 756-70.

[34] Paterson AC. Bacteriocinogeny and lysogeny in the genus Pseudomonas. J Gen Microbiol 1965; 39: 295-303.

[35] Michel-Briand Y, Baysee C. The pyocins of Pseudomonas aeruginosa. Biochimie 2002; 84: 499-510.

[36] Fischer S, Godino A, Quesada JM, et al. Characterization of a phage-like pyocin from the plant growth-promoting rhizobacterium Pseudomonas fluorescens SF4c. Microbiology 2012; 158(6): 1493503.

[37] Weinel C, Nelson KE, Tummler B. Global features of the Pseudomonas putida KT2440 genome sequence. Environ Microbiol 2002 4(12): 809-18.

[38] Haag WL, Vidaver AK. Purification and characterization of Syringacin 4-A, a Bacteriocin from Pseudomonas syringae 4-A. Antimicrob Agents Chemother 1974; 6(1): 76-83

[39] Iwalokun BA, Akinsinde KA, Lanlenhin O, Onubogu CC. Bacteriocinogenicity and production of pyocins from Pseudomonas species isolated in Lagos, Nigeria. Afr J Biotechnol 2006; 5(11): 10727.

[40] Cuppels DA, Hanson RS, Kelman A. Isolation and characterization of a bacteriocin produced by Pseudomonas solanacearum. J Gen Microbiol 1978; 109: 295-303.

[41] Shawkey MD, Mills KL, Dale C, Hill GE. Microbial diversity of wild bird feathers revealed through culture-based and cultureindependent techniques. Microb Ecol 2005; 50: 40-7.

[42] Pietikainen J, Pettersson M, Baath E. Comparison of temperature effects on soil respiration and bacterial and fungal growth rates. FEMS Microbiol Ecol 2005; 52: 49-58.

[43] Bisson IA, Marra PP, Burtt EH, Sikaroodi M, Gillevet PM. A molecular comparison of plumage and soil bacteria across biogeographic, ecological, and taxonomic scales. Microb Ecol 2007; 54: $65-81$.

Received: June 22,2013

Revised: July 28, 2013

Accepted: August 05, 2013

(C) Potter et al.; Licensee Bentham Open.

This is an open access article licensed under the terms of the Creative Commons Attribution Non-Commercial License (http://creativecommons.org/licenses/by-nc/3.0/) which permits unrestricted, non-commercial use, distribution and reproduction in any medium, provided the work is properly cited. 